Supporting Information

\title{
Enhancing C-C Bond Scission for Efficient Ethanol Oxidation using PtIr Nanocube Electrocatalysts
}

Qiaowan Chang1, Shyam Kattel ${ }^{2}$, Xing Li ${ }^{3,4}$, Zhixiu Liang ${ }^{3}$, Brian M. Tackett ${ }^{5}$, Steven R. Denny ${ }^{5}$, Pu Zhang ${ }^{1}$, Dong Su${ }^{3}$, Jingguang G. Chen, ${ }^{5,6^{*}}$ Zheng Chen ${ }^{1,7^{*}}$

${ }^{1}$ Department of NanoEngineering, University of California San Diego, La Jolla, California 92093, United States

${ }^{2}$ Department of Physics, Florida A\&M University, Tallahassee, Florida 32307, United States

${ }^{3}$ Center for Functional Nanomaterials, Brookhaven National Laboratory, Upton, New York 11973, United States

${ }^{4}$ Key Laboratory of Material Physics, Ministry of Education, Department of Physics and Engineering, Zhengzhou University, Zhengzhou 450052, China

${ }^{5}$ Department of Chemical Engineering, Columbia University, New York, New York 10027, United States

${ }^{6}$ Chemistry Division, Brookhaven National Laboratory, Upton, New York 11973, United States

${ }^{7}$ Program of Chemical Engineering, University of California San Diego, La Jolla, California 92093, United States

*E-mail: jgchen@columbia.edu,*E-mail: zhengchen@eng.ucsd.edu 


\section{Experimental Details}

\section{Synthesis of Pt and PtIr NCs}

Pt NCs were prepared by a solution method. ${ }^{1}$ In a typical synthesis, $20 \mathrm{mg}$ of Pt(acac)2 (Chem-Impex, 98\%) was dissolved in a mixed solution containing $7 \mathrm{ml}$ of benzyl ether (Sigma-Aldrich, 98\%), $1 \mathrm{ml}$ of oleic acid (Sigma-Aldrich, 90\%), and $2 \mathrm{ml}$ of oleylamine (Sigma-Aldrich, 70\%). The solution was heated to $130{ }^{\circ} \mathrm{C}$ under Ar protection and then $\mathrm{W}(\mathrm{CO})_{6}$ (Sigma-Aldrich, 97\%) was added during the heating process. Pt NCs were obtained after heating the solution to $235^{\circ} \mathrm{C}$ for $40 \mathrm{~min}$. Then the resulted colloidal products were centrifuged and washed using $5 \mathrm{ml}$ of toluene and $10 \mathrm{ml}$ of ethanol. After centrifugation, the Pt NCs were mixed with $12 \mathrm{mg}$ of Ketjen black (C) and then dispersed in $10 \mathrm{ml}$ of toluene for $3 \mathrm{~h}$ by ultrasonication. After dispersion, the Pt NCs/C were collected and dried at $60{ }^{\circ} \mathrm{C}$ for $3 \mathrm{~h}$. PtIr NCs/C were prepared in the same way with adding $\operatorname{Ir}($ acac) 3 (Sigma-Aldrich, 97\%) into the precursor solution. For PtIr $\mathrm{NCs} / \mathrm{C}, 10$ and $20 \mathrm{mg}$ of $\operatorname{Ir}(\mathrm{acac})_{3}$ was used for the synthes is of $\mathrm{Pt}_{38} \mathrm{Ir} \mathrm{NCs} / \mathrm{C}$ and $\mathrm{Pt}_{17} \mathrm{Ir} \mathrm{NCs} / \mathrm{C}$, respectively. For the preparation of $\mathrm{Pt}_{12} \mathrm{Ir} \mathrm{NCs} / \mathrm{C}, 12 \mathrm{mg}$ of $\mathrm{Pt}(\mathrm{acac})_{2}$ and $18 \mathrm{mg}$ of $\operatorname{Ir}(\mathrm{acac})_{3}$ were used.

\section{Characterization}

The size and morphology of the NC samples were characterized by transmission electron microscopy (TEM, JEOL JEM2100F). High-angle annular dark-field scanning TEM (HAADF-STEM) images were acquired by Hitachi HD 2700C and energy dispersive X-ray spectroscopy (EDS) analyses were performed using a FEI Talos F200X. X-ray diffraction (XRD) patterns were obtained by an X-ray diffractometer equipped with a $\mathrm{Cu} \mathrm{K} \alpha$ radiation source $(\lambda=1.5406 \AA$ ) at $40 \mathrm{kV}$ and $20 \mathrm{~mA}$ (Bruker AXS). The bulk compositions of PtIr alloys were determined by inductively coupled plasma mass spectrometry (ICP-Mass, iCAP Qc, Thermo Fisher Scientific). PtIr NCs/C were dissolved by a mixture of $\mathrm{HF}$ and $\mathrm{HNO}_{3}$ (volume ratio of 3:1). The solution was heated to $90^{\circ} \mathrm{C}$ for $72 \mathrm{~h}$. After cooling down to room temperature, the solution was mixed with $\mathrm{HF}$ and $\mathrm{HNO}_{3}$ (volume ratio of 3:1) again and heated to $60{ }^{\circ} \mathrm{C}$ for $24 \mathrm{~h}$. The surface composition of PtIr NCs was determined by a commercial SPECS Ambient-pressure X-ray photoelectron spectrum (AP-XPS) chamber equipped with a PHOIBOS 150 EP MCD-9 analyzer and the result was checked by repeating XPS test for 3 times. Equation S1, adapted from reference, ${ }^{2}$ was used for XPS analysis. The equation describes the XPS signal intensity ratio for a thin overlayer of one material on top of an infinitely thick substrate. 


$$
\frac{I_{A} / S_{A}}{I_{B} / S_{B}}=\frac{1-\exp \left[-\frac{d}{\lambda_{I M F P}^{A}\left(E_{A}\right) \cos \theta}\right]}{\exp \left[-\frac{d}{\lambda_{I M F P}^{A}\left(E_{B}\right) \cos \theta}\right]}
$$

In the equation, $A$ refers to the overlayer material (Ir), and $B$ refers to the substrate material (Pt). $I$ is XPS signal intensity, quantified by peak areas. $S$ is atomic sensitivity factor. $\lambda$ is inelastic mean free path of a photoelectron traveling through the overlayer material with energy, E. Due to the similarity in $\mathrm{Pt} 4 f$ and $\mathrm{Ir}$ $4 f$ electron binding energies, a single value of $\lambda=1.684 \mathrm{~nm}$ was used in both the numerator and denominator. $\theta$ is the photoemission angle relative to the surface normal, considered to be zero for these calculations. $d$ is the thickness of the overlayer.

\section{Electrochemical measurements}

A three-electrode system was used in electrochemical measurements, where a $\mathrm{Pt}$ wire and $\mathrm{Ag} / \mathrm{AgCl}(3 \mathrm{M}$ $\mathrm{Cl}^{-}$) were used as the counter and reference electrode, respectively. All the potentials were calibrated to a reversible hydrogen electrode (RHE). For the ink preparation, $2.5 \mathrm{mg}$ of $\mathrm{Pt} / \mathrm{C}$ or PtIr/C electrocatalysts were homogenously dispersed in a mixture solution containing $2.0 \mathrm{ml}$ of Milli-Q water, $0.5 \mathrm{ml}$ of isopropanol and $10 \mu \mathrm{l}$ of Nafion (5\%). $10 \mu \mathrm{l}$ of each catalyst ink was deposited on a pre-cleaned glassy carbon (GC) electrode. In the cyclic voltammetry (CV) measurement, electrocatalysts were first cleaned in Ar-saturated $0.1 \mathrm{M} \mathrm{HClO}_{4}$ solution with a scanning rate of $100 \mathrm{mV} \mathrm{s}^{-1}$ in the voltage range of $0.05 \sim 1.20$ V (vs. RHE) for 20 cycles. Then stabilized CV curves were obtained with a scanning rate of $50 \mathrm{mV} \mathrm{s}^{-1}$. For EOR measurements, CV curves were recorded in Ar-saturated $0.1 \mathrm{M} \mathrm{HClO}_{4}$ solution containing 0.2 $\mathrm{M}$ of $\mathrm{C}_{2} \mathrm{H}_{5} \mathrm{OH}$ with a scanning rate of $50 \mathrm{mV} \mathrm{s}^{-1}$. Chronoamperometric (CA) curves in terms of steadystate activity for EOR were measured at $0.45 \mathrm{~V}$ vs. RHE. Stability test was performed by holding potential at $0.45 \mathrm{~V}$ vs. RHE for every $10000 \mathrm{~s}$ followed by CV cleaning using a scanning rate of $100 \mathrm{mV} \mathrm{s}^{-1}$ in the voltage range of $0.05 \sim 1.20 \mathrm{~V}$ (vs. RHE) for 20 cycles. During the stability test, 3 cycles of $10000 \mathrm{~s}$ was examined. In CO stripping experiments, the potential of pre-cleaned electrode was held at $0.05 \mathrm{~V}$ for 10 min in a $\mathrm{CO}$-saturated $0.1 \mathrm{M} \mathrm{HClO}_{4}$ solution for $\mathrm{CO}$ adsorption. After purging $\mathrm{Ar}$ for 30 min to clear excess $\mathrm{CO}$ in the cell, $\mathrm{CO}$ stripping curves were taken with a scanning rate of $50 \mathrm{mV} \mathrm{s}^{-1}$. 


\section{In-situ infrared reflection-absorption spectroscopy (IRRAS)}

Nicolet IS50 spectrometer equipped with a mercuric cadmium telluride (MCT) detector was used in IRRAS measurements. The homemade electrochemical cell is consisted of a $\mathrm{ZnSe}$ hemisphere window and three electrodes, including an $\mathrm{Au}$ working electrode, a $\mathrm{Ag} / \mathrm{AgCl}$ reference electrode and a $\mathrm{Pt}$ mesh counter electrode. ${ }^{3}$ To avoid possible signal interference, the chamber was purged with compressed air $\left(\mathrm{CO}_{2}\right.$ and $\mathrm{H}_{2} \mathrm{O}$-free) to remove water moisture and $\mathrm{CO}_{2}$ before collecting FTIR spectra. To get the product distribution during $\mathrm{CV}$ measurement, spectra were recorded from 0.05 to $1.05 \mathrm{~V}$ (vs. RHE) by every 0.1 $\mathrm{V}$. The resolution was $4 \mathrm{~cm}^{-1}$ and 127 interferograms were together added to each spectrum. The final FTIR spectra were acquired by subtracting the first spectrum as the reference. To obtain the exact generation time of $\mathrm{CO}_{2}$, spectra was collected by holding the potential at $0.45 \mathrm{~V}$ vs. RHE for $600 \mathrm{~s}$. The electrolytes in this experiment were $0.1 \mathrm{M} \mathrm{HClO}_{4}$ solution containing $0.2 \mathrm{M}_{\text {of }} \mathrm{C}_{2} \mathrm{H}_{5} \mathrm{OH}$.

\section{Density function theory (DFT) calculations}

Spin-polarized density functional theory (DFT) calculations were performed using Vienna Ab-Initio Simulation Package (VASP) code. ${ }^{4-5}$ Projector augmented wave potentials were used to describe the core electrons with the generalized gradient approximation (GGA), using PW91 functionals. ${ }^{6}$ The Kohn-Sham one-electron wave functions were expanded by using a plane wave basis set with a kinetic energy cutoff of $400 \mathrm{eV}$. The Brillouin zone was sampled using a $3 \times 3 \times 1$ k-point grid in the Monkhorst-Pack scheme. ${ }^{7}$ The $\mathrm{Pt}(100)$ surface was modeled using a four layer $3 \times 3$ surface slab. The $\operatorname{Ir}_{4} \mathrm{Pt}_{5}(100)$ surface was modeled by replacing four of the surface Pt atoms with Ir atoms, and Ir-ML-Pt(100) surface was obtained by replacing all surface Pt with Ir. A $14 \AA$ thick vacuum was added along the direction perpendicular to the surface in the initial slab model to avoid the artificial interactions between the slab and its periodic images. During geometry optimization, the atoms in the bottom two layers were fixed while all other atoms including adsorbates were allowed to relax until Hellman-Feynman force on each ion was smaller than $0.02 \mathrm{eV} / \AA$. The binding energy (B.E.) of an adsorbate is calculated as:

$$
\text { B.E. }=E(\text { slab+adsorbate })-E(\text { slab })-E(\text { adsorbate })
$$

where $E$ (slab+adsorbate), $E$ (slab) and $E$ (adsorbate) are total energies of optimized slab+adsorbate, slab and adsorbate configurations, respectively. 


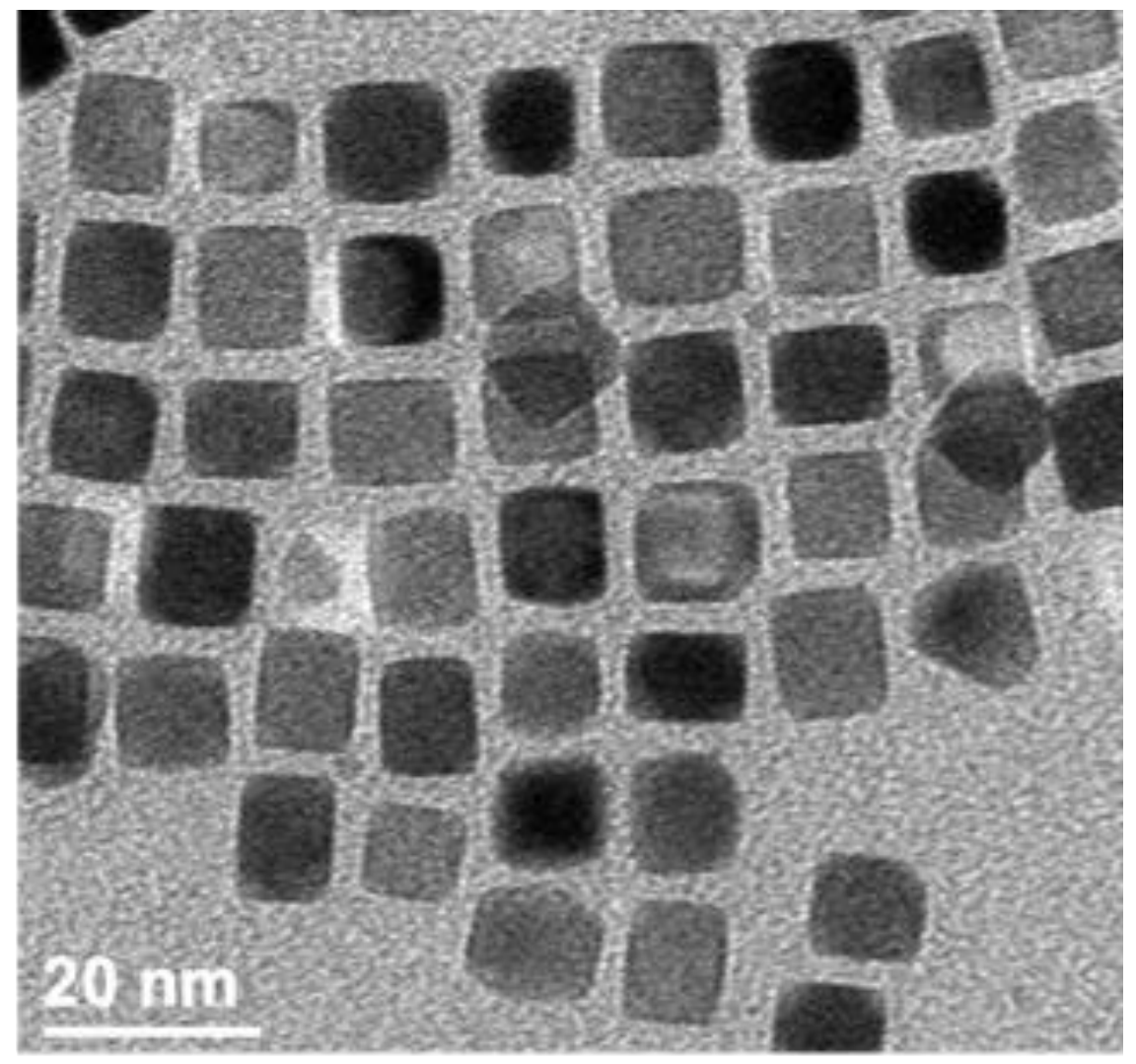

Figure S1. Low-magnification TEM image of as-synthesized Pt NCs. 
(A)

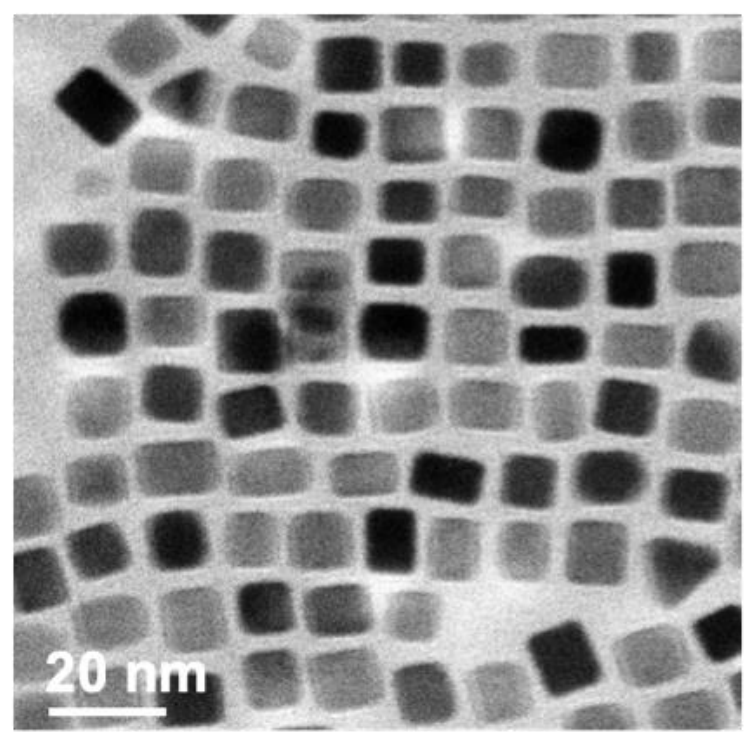

(C)

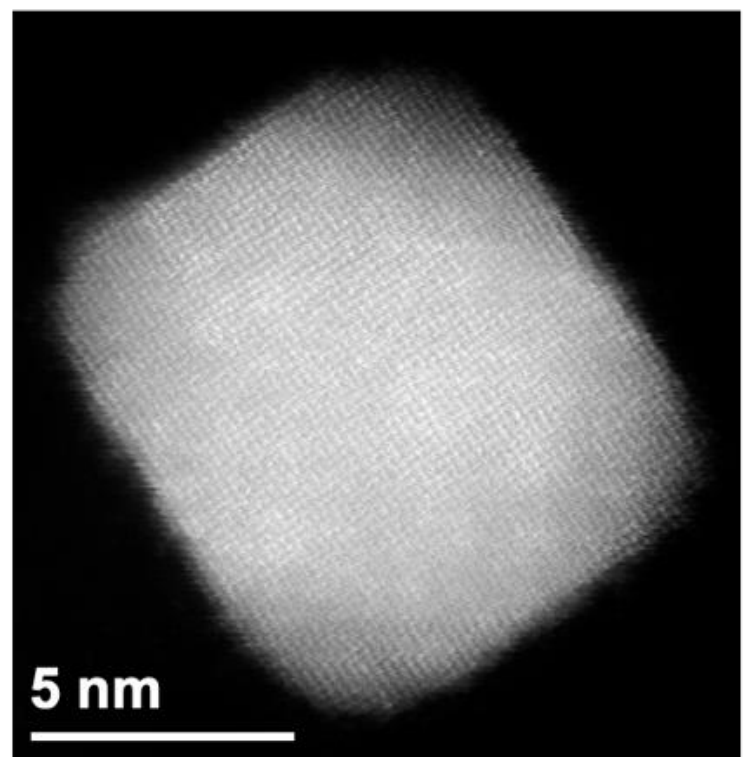

(B)

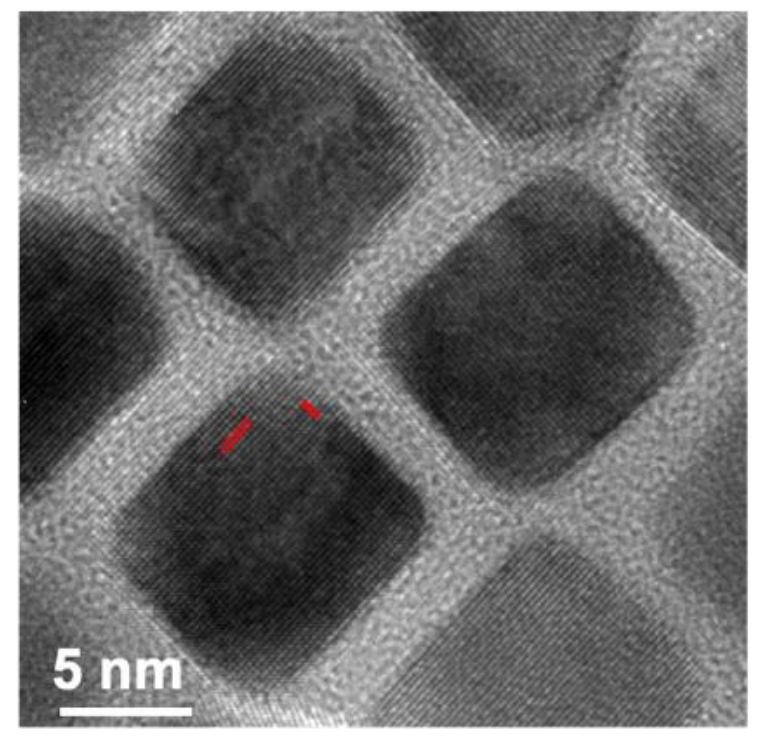

(D)

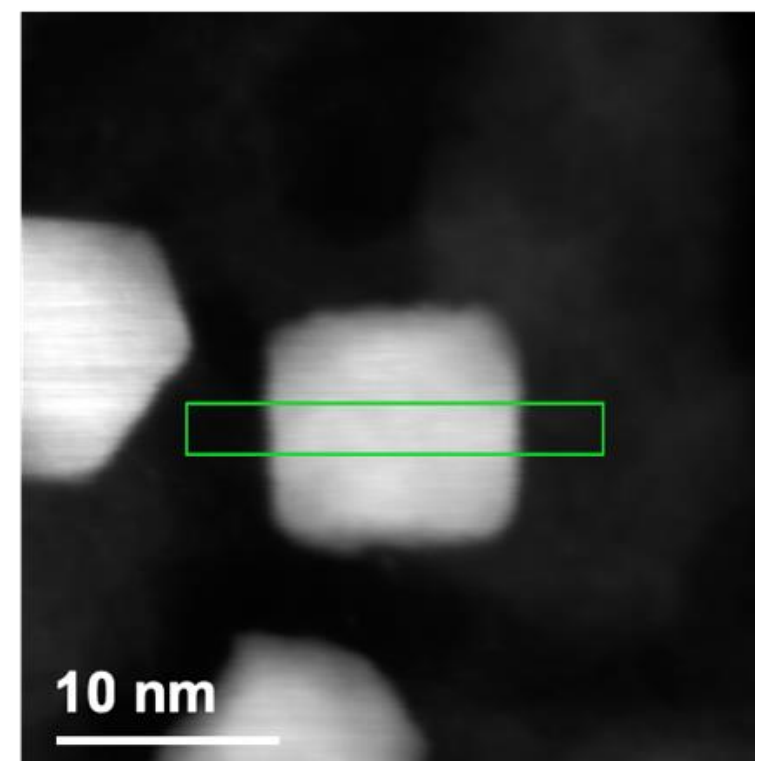

Figure S2. Low-magnification TEM image (A), HRTEM image (B) of as-obtained Pt 38 Ir NCs. Atomic resolution HAADF-STEM image along the $\langle 100\rangle$ zone axis (C) and ADF-STEM image (D) of a single $\mathrm{Pt}_{38} \mathrm{Ir}$ NC. The highlighted area (green region in D) corresponds to the detailed EDS cross-sectional element mapping shown in Fig 1I of a single Pt 38 Ir NC in the main text. 
(A)

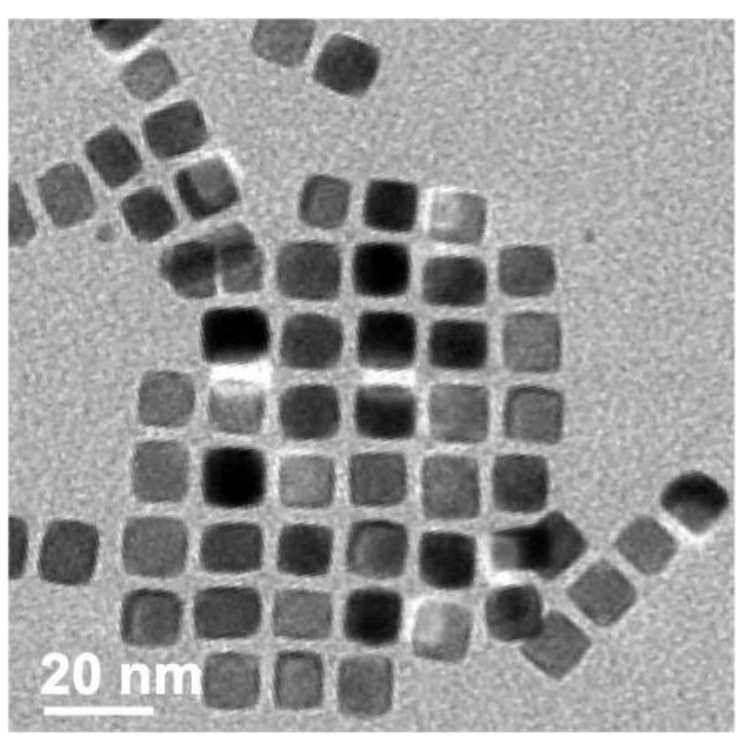

(C)

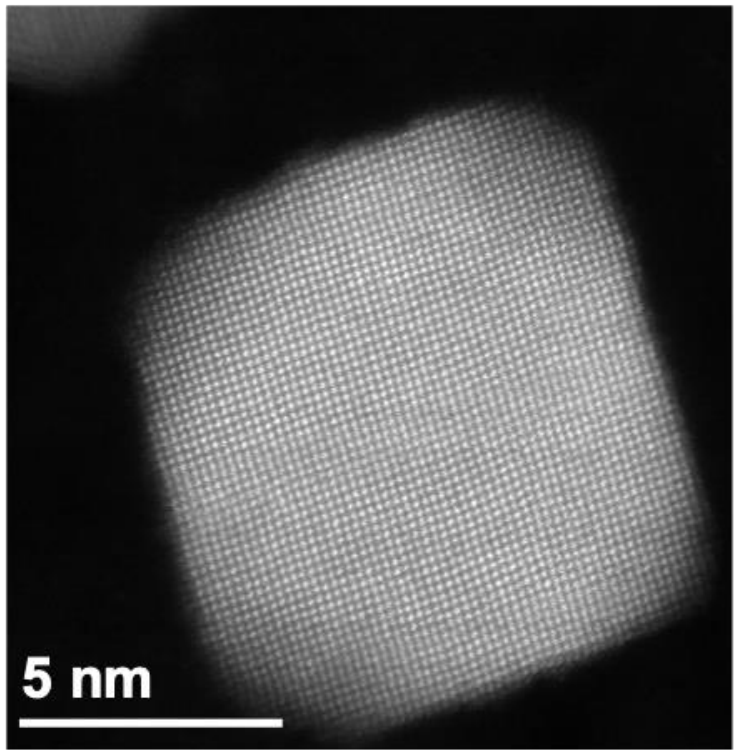

(B)

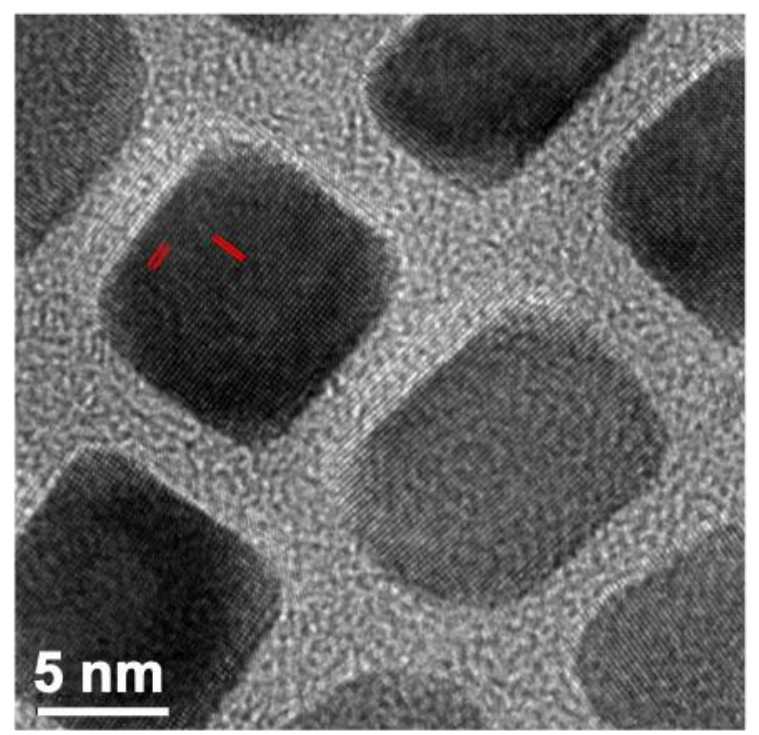

(D)

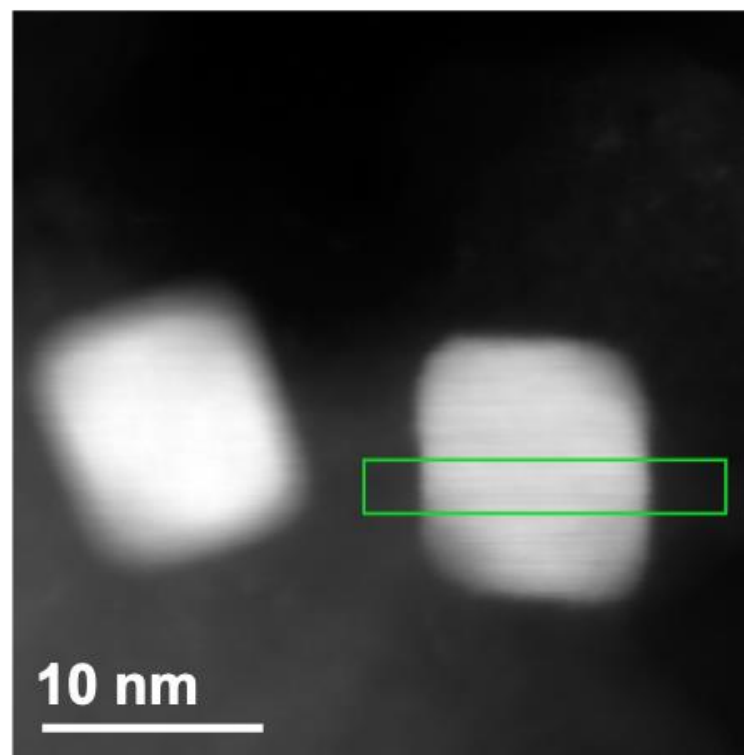

Figure S3. Low-magnification TEM image (A), HRTEM image (B) of as-obtained $\mathrm{Pt}_{17} \mathrm{Ir}_{\mathrm{NCs}}$. Atomic resolution HAADF-STEM image along the <100> zone axis (C) and ADF-STEM image (D) of a single $\mathrm{Pt}_{17} \mathrm{Ir}$ NC. The highlighted area (green region in D) corresponds to the detailed EDS cross-sectional element mapping shown in Fig $1 \mathrm{~K}$ of a single $\mathrm{Pt}_{17} \mathrm{Ir} \mathrm{NC}$ in the main text. 


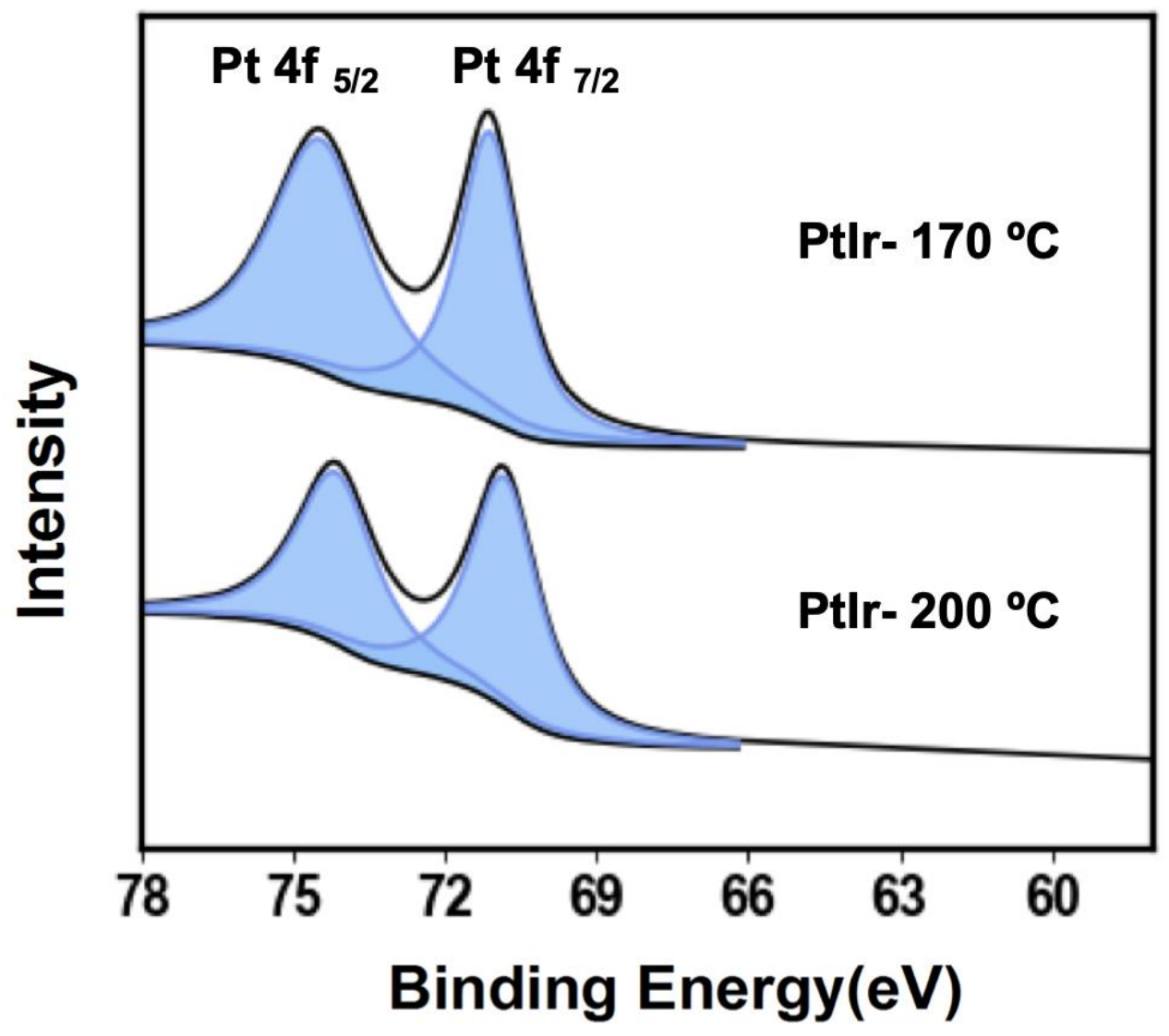

Figure S4. XPS spectra of PtIr intermediates formed at 170 and $200{ }^{\circ} \mathrm{C}$ during the synthesis of Pt $38 \mathrm{Ir}$ NCs. The composition of the precursor solution was maintained the same except for the different reaction temperature. 


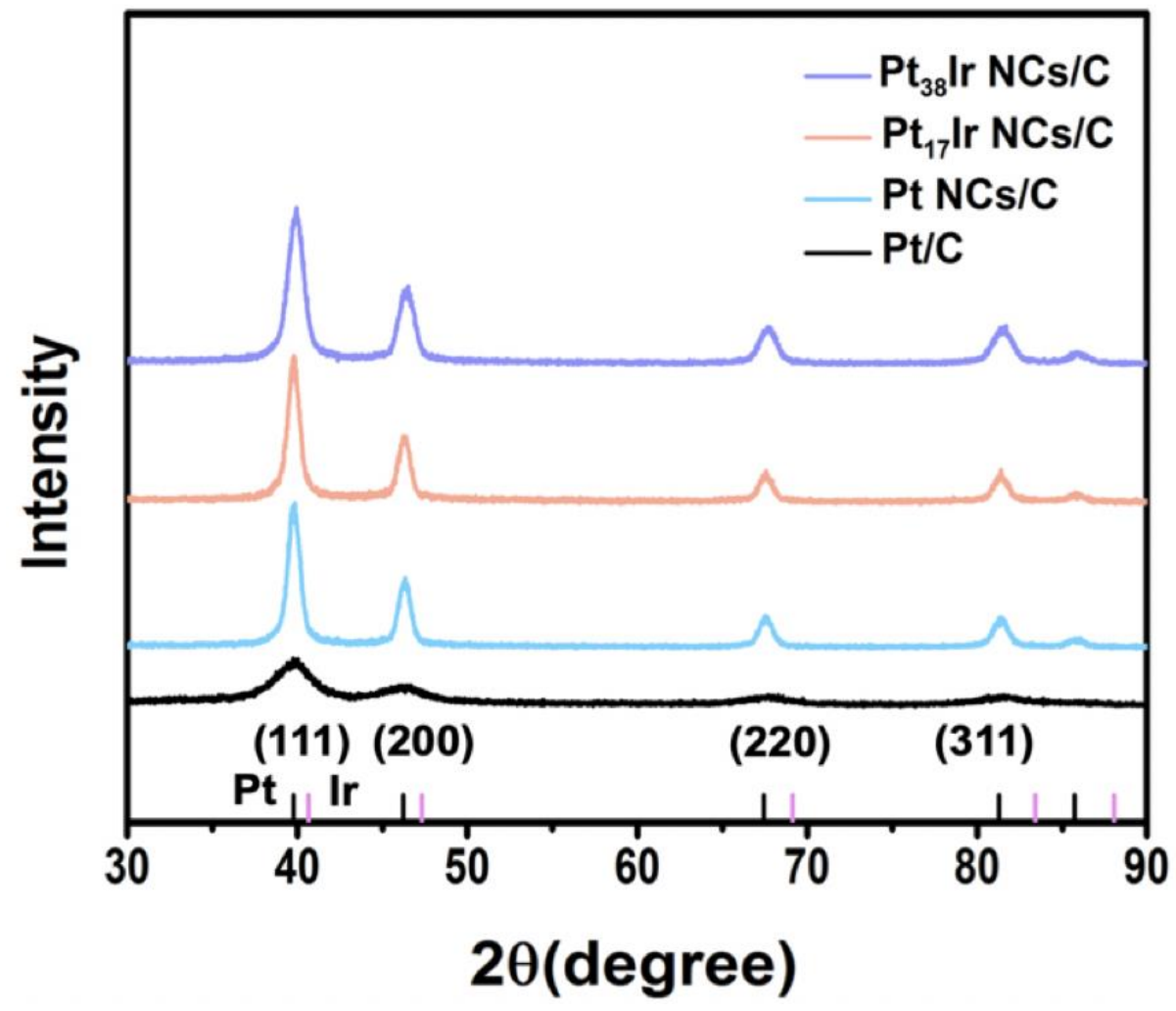

Figure S5. Powder XRD patterns of prepared $\mathrm{Pt} \mathrm{NCs} / \mathrm{C}, \mathrm{Pt}_{38} \mathrm{Ir} \mathrm{NCs} / \mathrm{C}$ and $\mathrm{Pt}_{17} \mathrm{Ir} \mathrm{NCs}_{\mathrm{N}} / \mathrm{C}$ electrocatalysts. A commercial $\mathrm{Pt} / \mathrm{C}$ (E-TEK, 20\% Pt/C) was also examined as a reference material. 


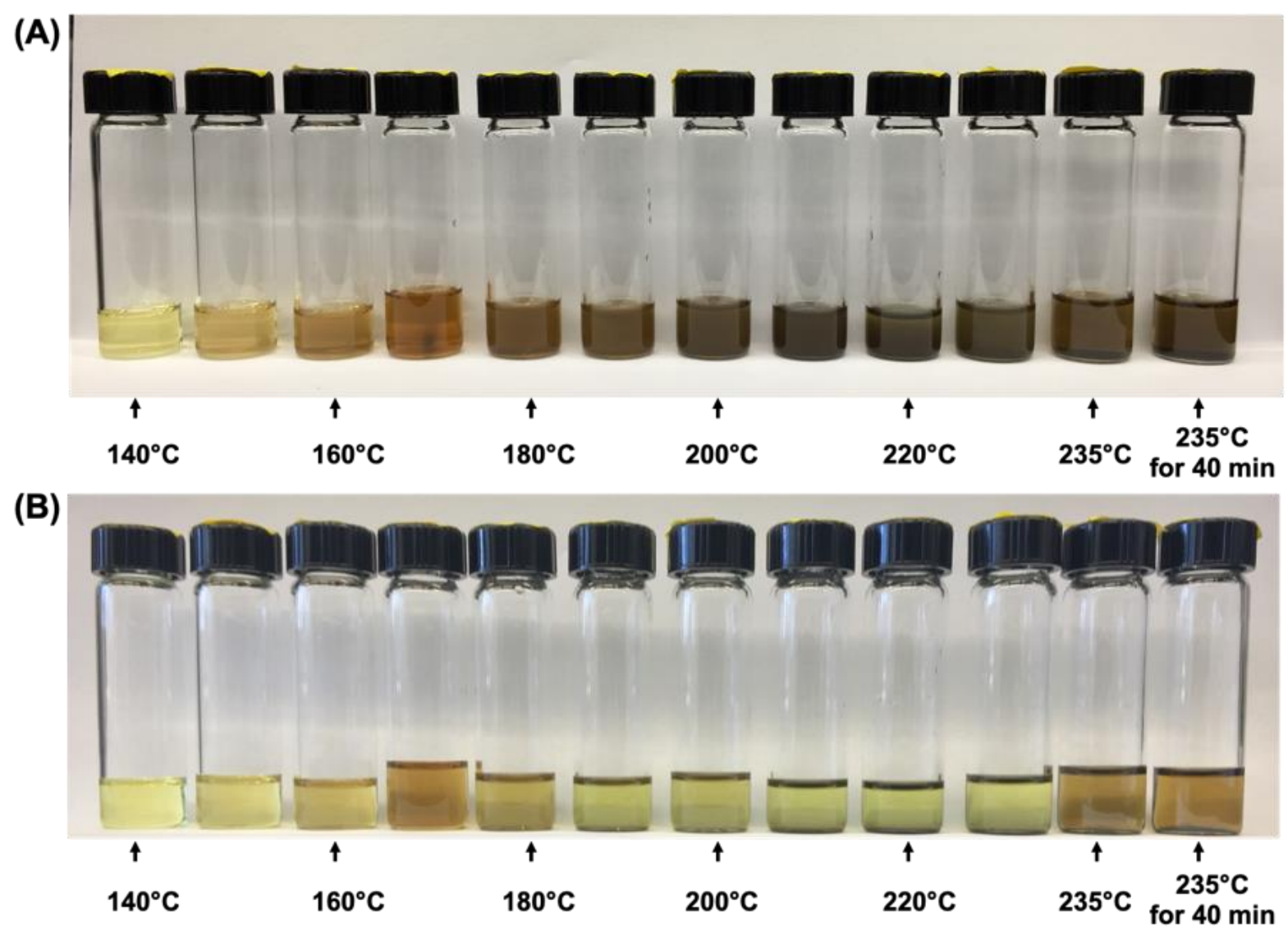

Figure S6. Representative solutions taken from the reaction flask right after reaction (A) and after particle precipitation (B) from reaction temperature in the range of 140 to $235^{\circ} \mathrm{C}$. The last vial on the right side shows the solution sample obtained after holding the reaction temperature at $235^{\circ} \mathrm{C}$ for $40 \mathrm{~min}$, and the rest samples are obtained without holding at the respective reaction temperature. As indicated by the color of each solutions, NC particles begin to form starting from a temperature of $180^{\circ} \mathrm{C}$. 


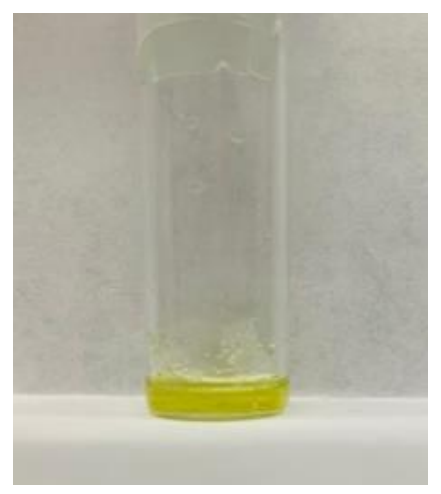

Figure S7. Representative Ir-reaction solution obtained from the reaction flask. In the attempt to synthesize Ir NCs, $20 \mathrm{mg}$ of $\operatorname{Ir}(\mathrm{acac})_{3}$ (Sigma-Aldrich, 97\%) was dissolved in a mixed solution containing $7 \mathrm{ml}$ of benzyl ether (Sigma-Aldrich, 98\%), $1 \mathrm{ml}$ of oleic acid (Sigma-Aldrich, 90\%), and $2 \mathrm{ml}$ of oleylamine (Sigma-Aldrich, 70\%). The solution was heated to $130{ }^{\circ} \mathrm{C}$ under Ar protection and then $\mathrm{W}(\mathrm{CO})_{6}$ (Sigma-Aldrich, 97\%) was added during the heating process. The solution sample was taken after holding the reaction temperature at $235^{\circ} \mathrm{C}$ for $40 \mathrm{~min}$. As indicated by the color of the solution (no change during the heating process), no Ir NC particles can be produced. 


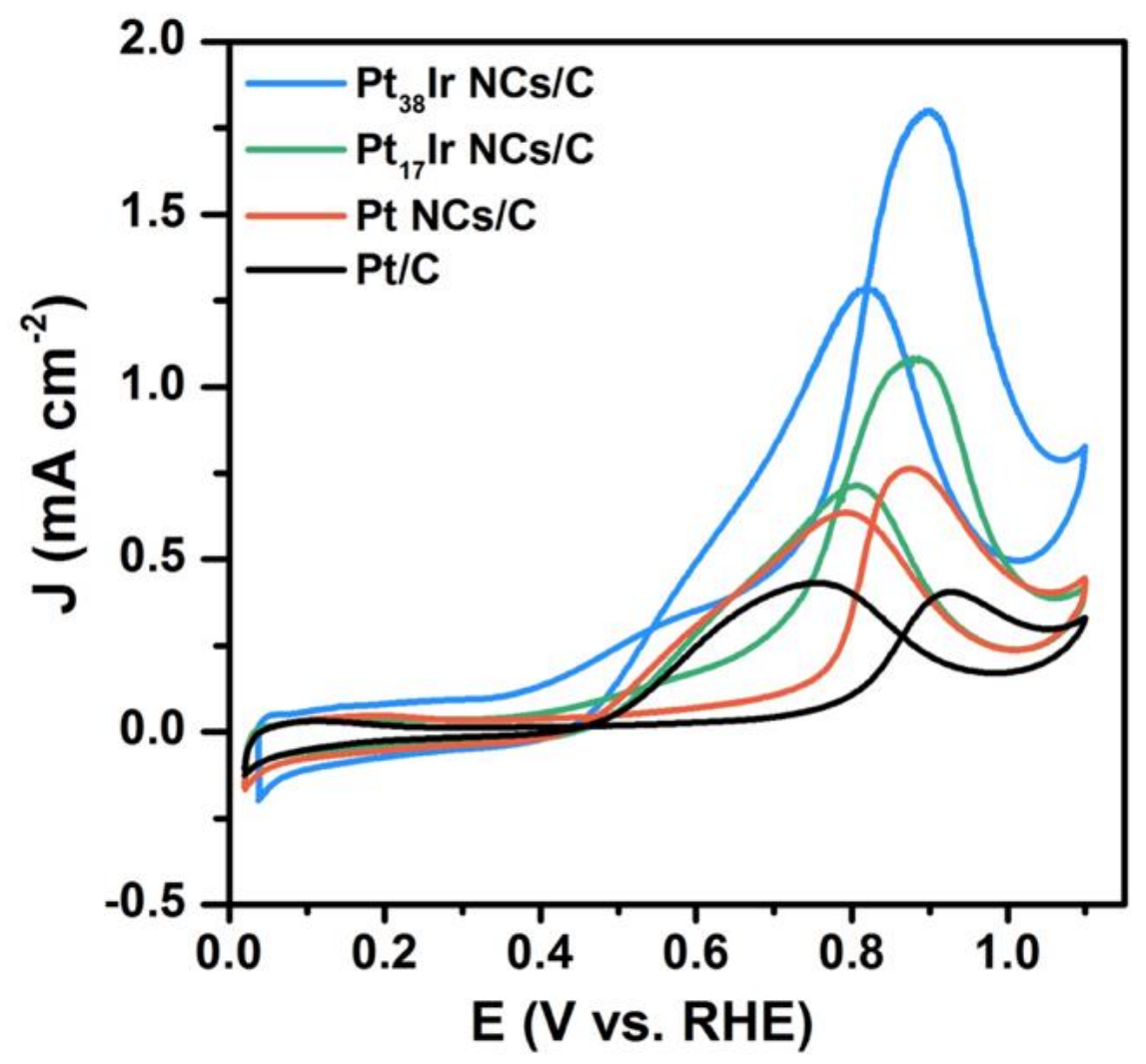

Figure S8. Electrochemical EOR curves of different electrocatalysts in an Ar-saturated $0.1 \mathrm{M} \mathrm{HClO}_{4}+$ $0.2 \mathrm{M}$ ethanol solution. The scan rate is $50 \mathrm{mV} \mathrm{s}$. The current densities are normalized to the electrochemical surface area. The peak ratio between forward scan and backward scan $\left(I_{f} / I_{b}\right)$ can provide qualitative estimation about the capability of each sample to break $\mathrm{C}-\mathrm{C}$ bond. ${ }^{8}$ It is generally considered that the higher the ratio is, the higher $\mathrm{CO}_{2}$ selectivity the sample can give. Among all the samples, the ratios follow the order by $\mathrm{Pt}_{17} \mathrm{Ir} \mathrm{NCs} / \mathrm{C}>\mathrm{Pt}_{38} \mathrm{Ir} \mathrm{NCs} / \mathrm{C}>\mathrm{Pt} \mathrm{NCs} / \mathrm{C}>$ commercial $\mathrm{Pt} / \mathrm{C}$. By combining the following in situ IRRAS result, it is found that this ratio can only presage the potential capability of the catalyst to break $\mathrm{C}$-C bond, not a quantitative measurement about its $\mathrm{CO}_{2}$ selectivity because $\mathrm{Pt}_{38} \mathrm{Ir} \mathrm{NCs} / \mathrm{C}$ presents better $\mathrm{CO}_{2}$ selectivity than $\mathrm{Pt}_{17} \mathrm{Ir}$ NCs/C based on in situ IRRAS result. 


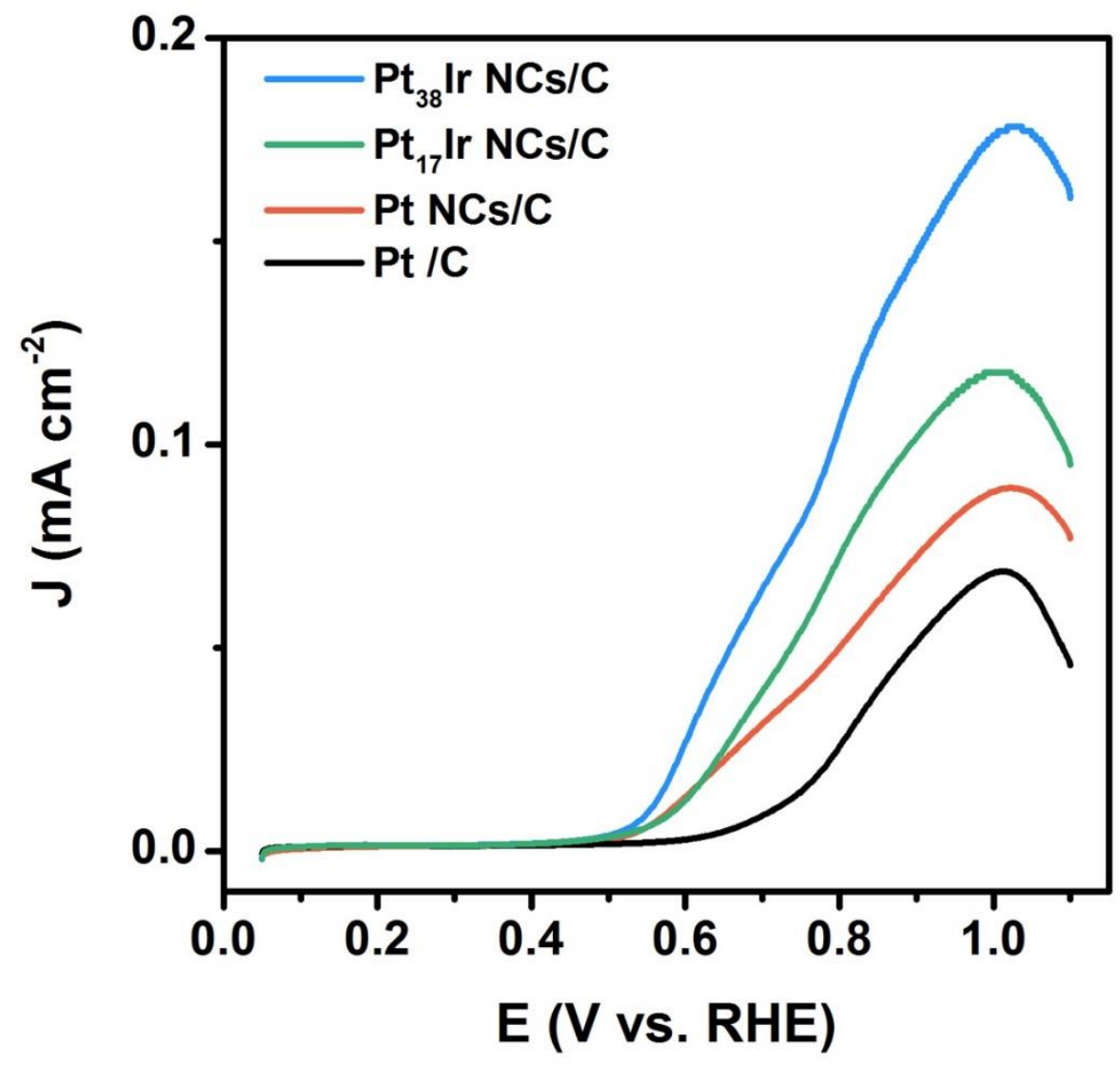

Figure S9. Anodic curves of electrochemical EOR for different samples collected during the in situ IRRAS experiment. The scan rate is $2 \mathrm{mV} \mathrm{s}^{-1}$. The current densities are normalized to the electrochemical surface area. 

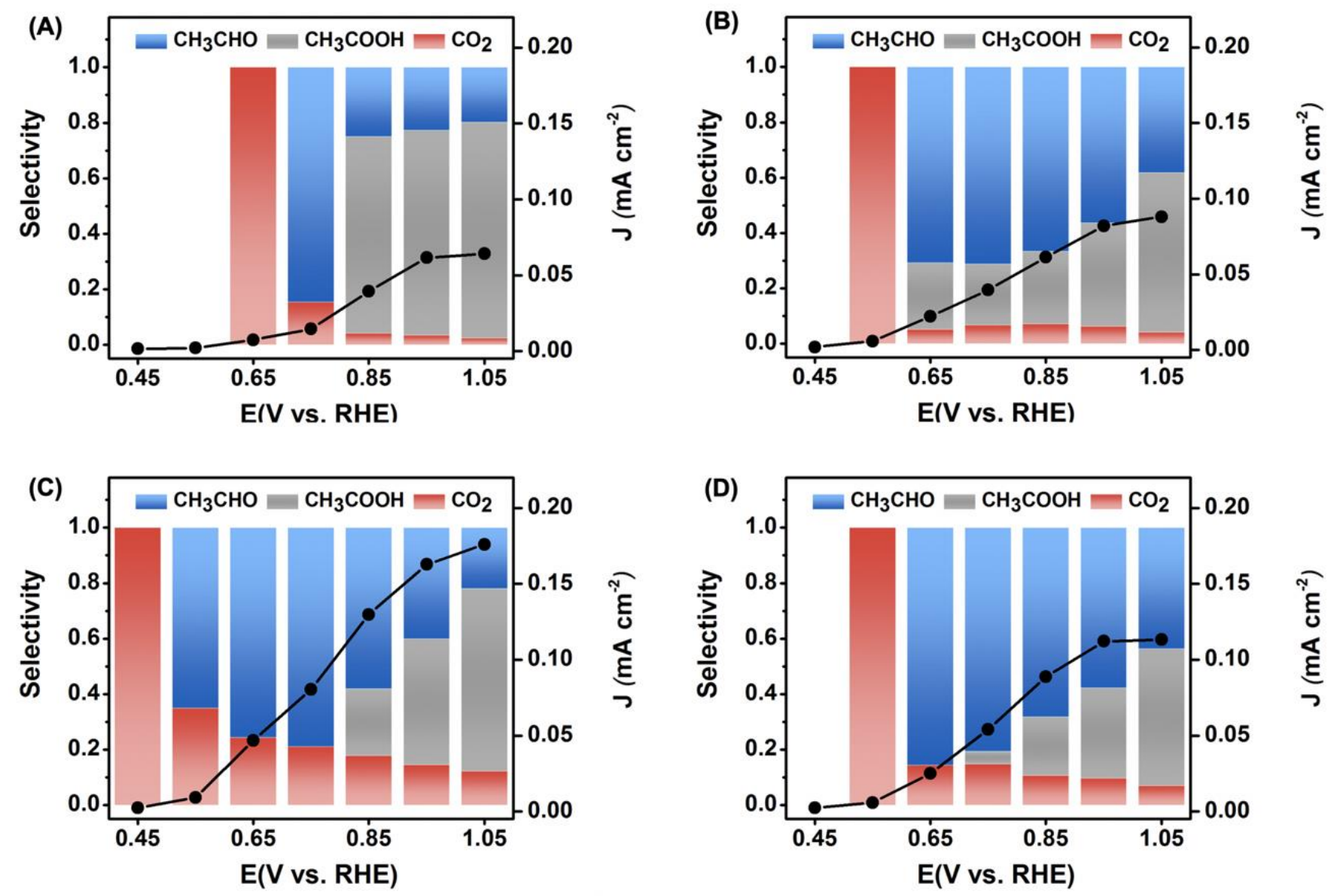

Figure S10. Calculated selectivity of different EOR products and overall current densities of all the electrocatalysts at different potentials: (A) commercial Pt/C, (B) Pt NCs/C, (C) Pt ${ }_{38} \mathrm{Ir}$ NCs/C and (D) $\mathrm{Pt}_{17} \mathrm{Ir}_{\mathrm{r}}$ $\mathrm{NCs} / \mathrm{C}$. The details of the calculation method are provided in the above experiment method section. 


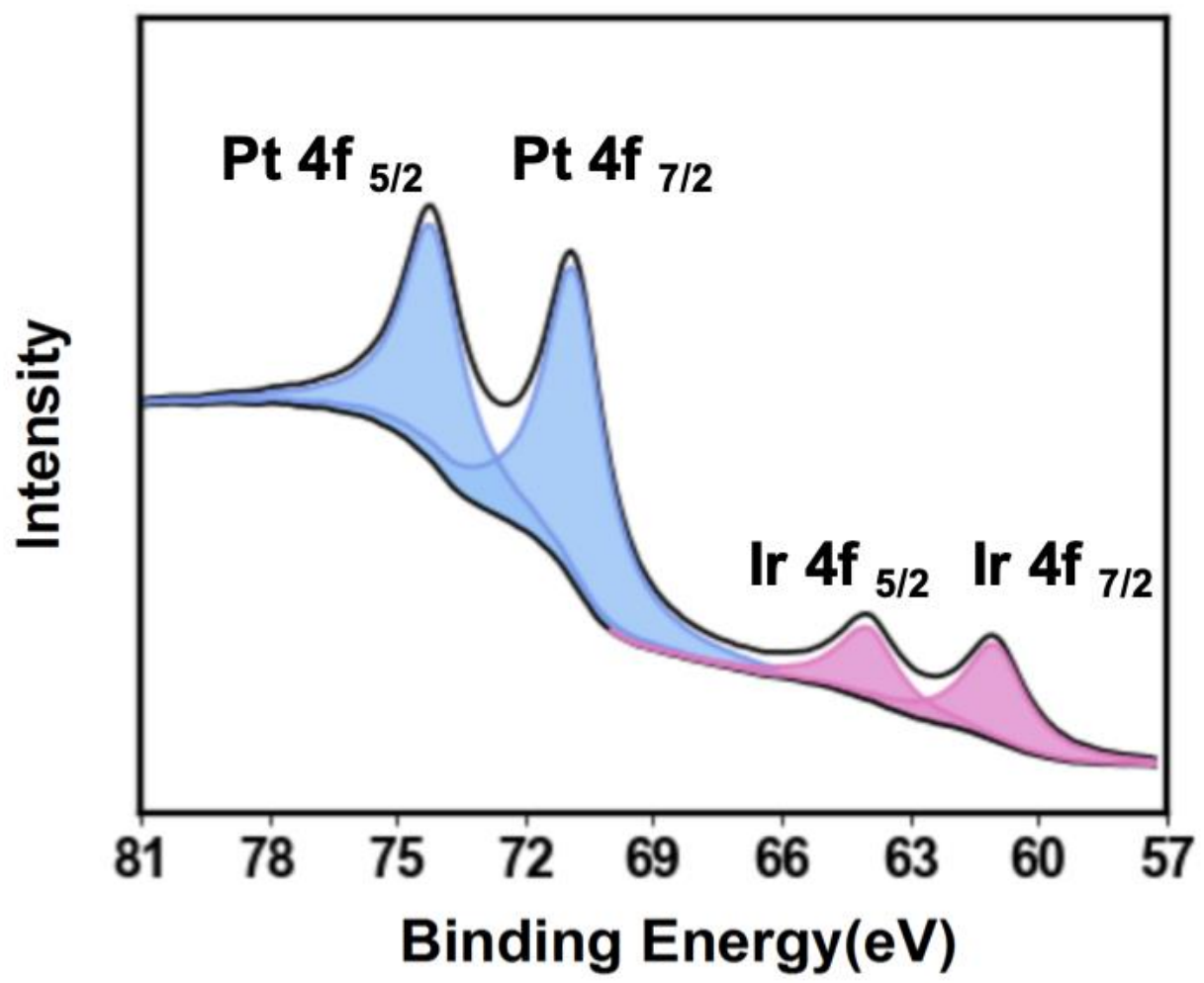

Figure S11. XPS spectra of as-obtained $\mathrm{Pt}_{12} \mathrm{Ir}$ NCs. The Pt $4 f$ peaks of $\mathrm{Pt}_{12} \mathrm{Ir}$ can be deconvoluted into peaks at $70.0\left(4 f_{7 / 2}\right)$ and $73.3 \mathrm{eV}\left(4 f_{5 / 2}\right)$. The Ir $4 f$ peaks can be deconvoluted into peaks at $60.2\left(4 f_{7 / 2}\right)$ and $63.2 \mathrm{eV}\left(4 f_{5 / 2}\right)$.

To further investigate the effect of Ir content in PtIr alloy catalyst on its EOR performance, here we tried to further increase the amount of $\operatorname{Ir}(\mathrm{acac})_{3}$ precursor in the solution (from Pt: $\mathrm{Ir}=1: 1$ for $\mathrm{Pt}_{17} \mathrm{Ir}$ to Pt: $\mathrm{Ir}=1: 1.5$ in mole). The bulk composition by ICP-MS is $\mathrm{Pt}_{12} \mathrm{Ir}$ and the XPS ratio of Ir/Pt is 0.34 . 


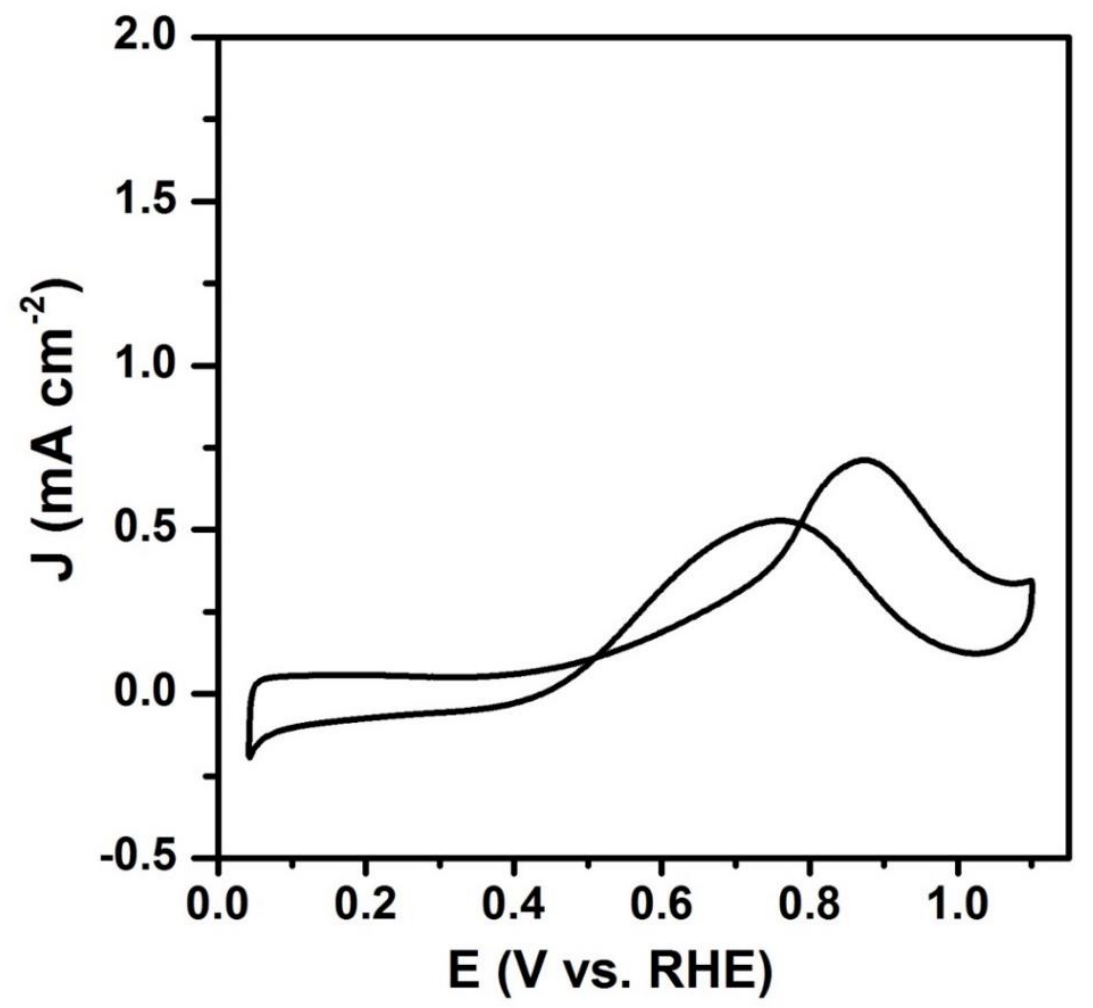

Figure S12. Electrochemical EOR curves of $\mathrm{Pt}_{12} \mathrm{Ir} / \mathrm{C}$. The test was performed in an Ar-saturated $0.1 \mathrm{M}$ $\mathrm{HClO}_{4}+0.2 \mathrm{M}$ ethanol solution with a scan rate of $50 \mathrm{mV} \mathrm{s}^{-1}$. The current density is normalized to the electrochemical surface area. The EOR activity $\left(0.7 \mathrm{~mA} \mathrm{~cm}{ }^{-2}\right)$ of $\mathrm{Pt}_{12} \mathrm{Ir} / \mathrm{C}$ was even lower than that of $\mathrm{Pt}$ $\mathrm{NCs} / \mathrm{C}\left(0.78 \mathrm{~mA} \mathrm{~cm}{ }^{-2}\right)$, suggesting that a too high Ir loading can deteriorate the EOR performance of the PtIr NC catalyst. 


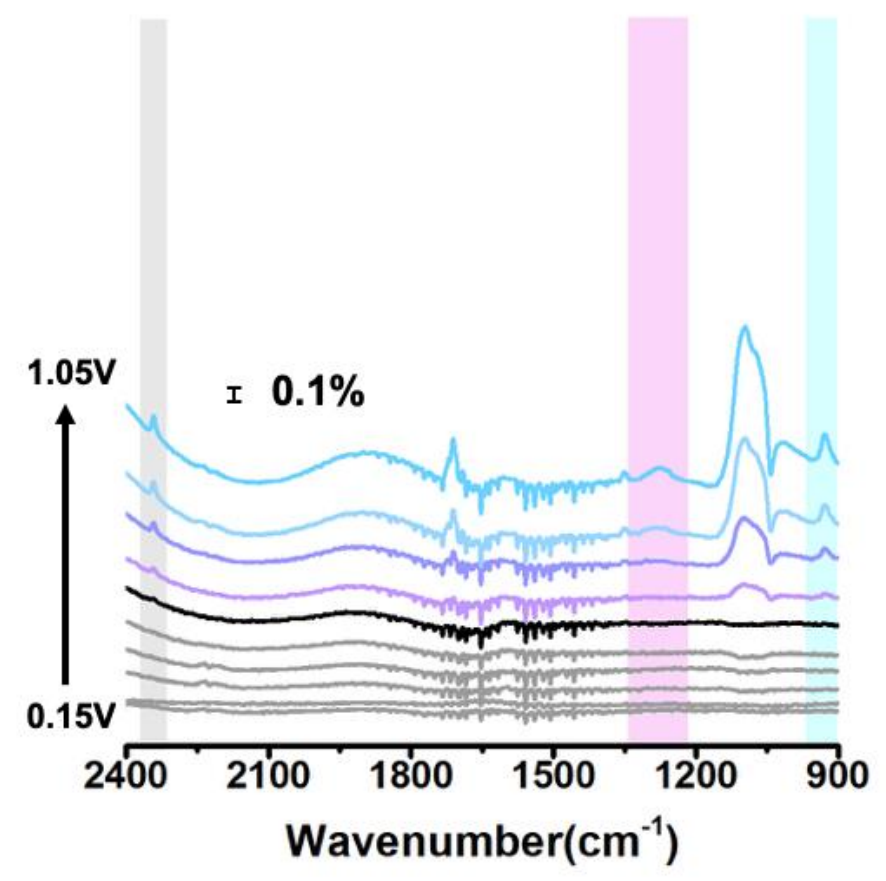

Figure S13. In-situ IRRAS spectra recorded during CV test from 0.15 to $1.05 \mathrm{~V}$ (vs. RHE) for EOR on $\mathrm{Pt}_{12} \mathrm{Ir} / \mathrm{C}$. The data recording interval is $0.1 \mathrm{~V}$. The peaks under the shaded area with grey, pink and blue color represents $\mathrm{CO}_{2}, \mathrm{CH}_{3} \mathrm{COOH}$ and $\mathrm{CH}_{3} \mathrm{CHO}$. The black curve in each spectrum shows the onset of $\mathrm{CO}_{2}$ production. The electrolyte was Ar-saturated $0.1 \mathrm{M} \mathrm{HClO}_{4}$ with $0.2 \mathrm{M}$ ethanol. All the experiments were performed at $25{ }^{\circ} \mathrm{C}$. It is found that $\mathrm{CO}_{2}$ cannot be produced until the oxidation potential reaches to 0.65 $\mathrm{V}$ (vs. RHE). Even at high potential, the amount of $\mathrm{CO}_{2}$ is still negligible. These results further confirm that a high Ir loading in the PtIr NCs catalyst is unfavorable for EOR. 
(A)
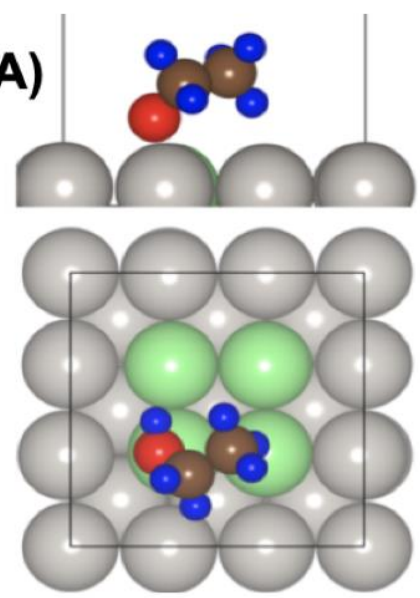

(D)
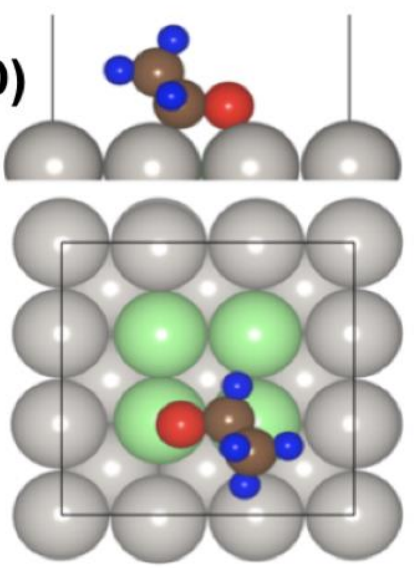

(B)
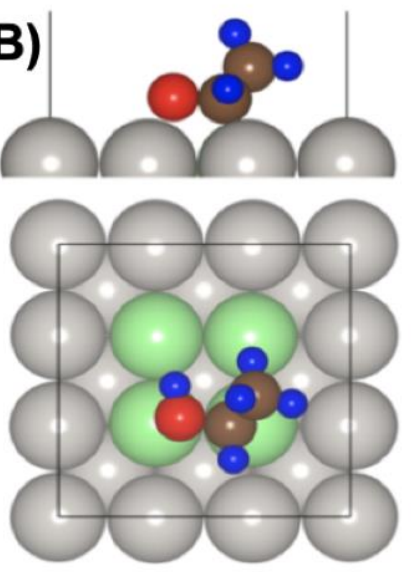

(E)
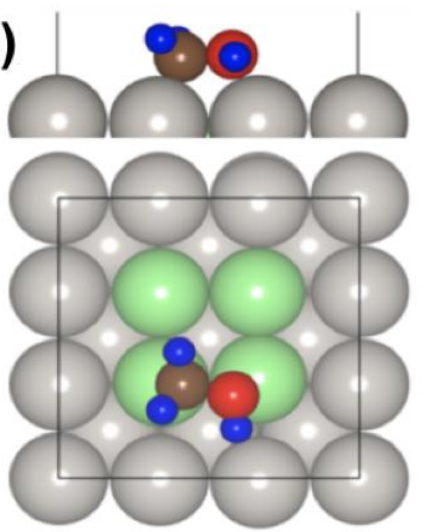

(C)

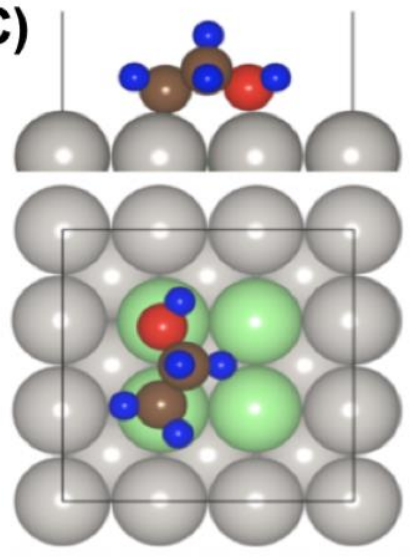

(F)

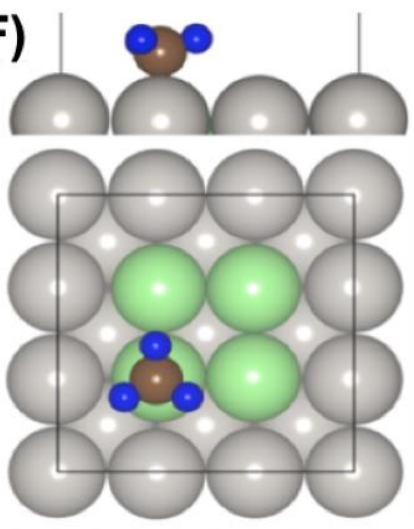

Figure S14. DFT optimized geometry of different EOR intermediates/products absorbed on PtIr (100) surface. (A) $\mathrm{CH}_{3} \mathrm{CH}_{2} \mathrm{OH}$, (B) $\mathrm{CH}_{3} \mathrm{CHOH}$, (C) $\mathrm{CH}_{2} \mathrm{CH}_{2} \mathrm{OH}$, (D) $\mathrm{CH}_{3} \mathrm{CHO}$, (E) $\mathrm{CH}_{2} \mathrm{OH}$, and (F) $\mathrm{CH}_{3}$. (Pt: gray, Ir: light green, $\mathrm{O}$ : red, $\mathrm{C}$ : brown and $\mathrm{H}$ : blue.) 


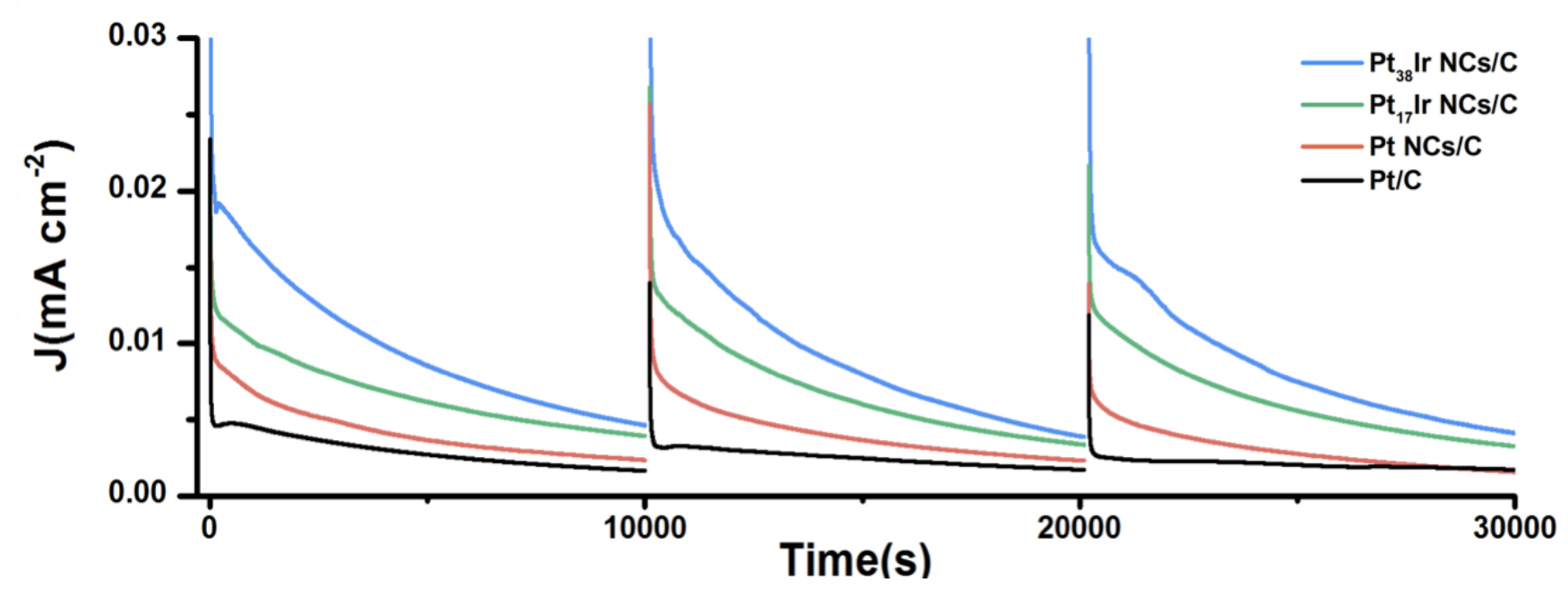

Figure S15. Electrochemical EOR stability test of all the electrocatalysts in an Ar-saturated $0.1 \mathrm{M} \mathrm{HClO}_{4}$ with $0.2 \mathrm{M}$ ethanol at $0.45 \mathrm{~V}$ (vs. RHE). The EOR current densities are normalized to the electrochemical surface area. All the experiments were performed at $25^{\circ} \mathrm{C}$. 
Table S1. Electrochemical surface area of different electrocatalysts.

\begin{tabular}{|c|c|c|c|c|}
\hline Electrocatalysts & $\begin{array}{l}\operatorname{ECSA}_{H} \\
\left(\mathrm{~m}^{2} \mathrm{~g}^{-1}\right)\end{array}$ & $\begin{array}{r}\operatorname{ECSA}_{\mathrm{CO}} \\
\left(\mathrm{m}^{2} \mathrm{~g}^{-1}\right)\end{array}$ & $\begin{array}{l}\text { Specific peak } \\
\text { current density } \\
\left(\mathrm{mA} \mathbf{c m}^{-2}\right)\end{array}$ & $I_{f} / I_{b}$ \\
\hline $\mathrm{Pt} / \mathrm{C}$ & 85.5 & 80.7 & 0.40 & 0.94 \\
\hline Pt NCs/C & 39.6 & 45.1 & 0.76 & 1.20 \\
\hline $\mathrm{Pt}_{17} \mathrm{Ir} \mathrm{NCs} / \mathrm{C}$ & 37.2 & 42.4 & 1.08 & 1.54 \\
\hline $\mathrm{Pt}_{38} \mathrm{Ir} \mathrm{NCs} / \mathrm{C}$ & 31.5 & 35.1 & 1.80 & 1.44 \\
\hline
\end{tabular}


Table S2. In-situ FTIR spectra bands assignments ${ }^{9-13}$.

\begin{tabular}{|c|c|}
\hline Wave number $\left(\mathbf{c m}^{-1}\right)$ & mode \\
\hline 2341 & $\mathrm{CO}_{2}$ asymmetric stretching in solution \\
\hline 2041 & Absorbed CO linearly bonded \\
\hline 1715 & $\begin{array}{c}\mathrm{C}=\mathrm{O} \text { stretching in } \mathrm{CH}_{3} \mathrm{CHO} \text { and } \\
\mathrm{CH}_{3} \mathrm{COOH} \text { in solution }\end{array}$ \\
\hline$\sim 1635$ & $\mathrm{H}-\mathrm{O}-\mathrm{H}$ bending of $\mathrm{H}_{2} \mathrm{O}$ \\
\hline $1620-1635$ & $\begin{array}{c}\mathrm{C}=\mathrm{O} \text { stretching of absorbed } \\
\text { acetaldehyde and acetyl }\end{array}$ \\
\hline 1550 & $\begin{array}{l}\mathrm{O}-\mathrm{C}-\mathrm{O} \text { asymmetric stretching of acetate } \\
\text { in solution }\end{array}$ \\
\hline 1438 & $\mathrm{CH}_{3}$ bending in acetic acid \\
\hline 1415 & $\mathrm{O}-\mathrm{C}-\mathrm{O}$ symmetric stretching of acetate \\
\hline $1355 / 1368$ & $\begin{array}{c}\mathrm{CH}_{3} \text { symmetric deformation in } \\
\mathrm{CH}_{3} \mathrm{CHO}\end{array}$ \\
\hline$\sim 1350$ & $\begin{array}{c}\text { Bicarbonate anions signals/O-C-O } \\
\text { symmetric stretching }\end{array}$ \\
\hline$\sim 1348 / 1383$ & $\begin{array}{l}\mathrm{CH} \text { in-plane bending mode of absorbed } \\
\text { acetate/acetate in solution }\end{array}$ \\
\hline 1280 & $\mathrm{C}-\mathrm{O}$ stretching in $\mathrm{CH}_{3} \mathrm{COOH}$ \\
\hline 1274 & $\begin{array}{l}\text { Associated to an intermediate } \\
\mathrm{CH}_{3} \mathrm{CH}(\mathrm{OH}) \mathrm{O}-\mathrm{Pt} \text { to acetate }\end{array}$ \\
\hline 1257 & $\begin{array}{l}\text { The } \mathrm{C}-\mathrm{O} \text { stretch of a species containing } \\
\text { a } \mathrm{COH} \text { group, indicating } \mathrm{Pt}_{2}-\mathrm{CH}_{3} \mathrm{CHO}\end{array}$ \\
\hline 1108 & $\mathrm{C}-\mathrm{H}$ wagging in $\mathrm{CH}_{3} \mathrm{CHO}$ \\
\hline 1044 & $\mathrm{C}-\mathrm{O}$ stretching of $\mathrm{CH}_{3} \mathrm{CH}_{2} \mathrm{OH}$ \\
\hline 933 & $\begin{array}{c}\text { C-C-O asymmetric stretching of } \\
\mathrm{CH}_{3} \mathrm{CHO}\end{array}$ \\
\hline
\end{tabular}


Table S3. Summary of the representative reports ECSA-normalized activity and selectivity toward $\mathrm{CO}_{2}$ at Pt-Ir and Pt-Rh alloys for the EOR.

\begin{tabular}{|c|c|c|c|c|c|}
\hline Electrocatalysts & $\begin{array}{l}\text { Specific } \\
\text { activity } \\
\left(\mathbf{m A ~} \mathbf{c m}^{-}\right. \\
2)\end{array}$ & $\begin{array}{l}\mathrm{CO}_{2} \text { onset } \\
\text { potential } \\
\text { (vs. } \mathrm{RHE})\end{array}$ & $\begin{array}{c}\mathrm{CO}_{2} \text { selectivity at } \\
0.75 \text { V vs. } \mathrm{RHE}\end{array}$ & $\begin{array}{l}\text { Measured } \\
\text { method }\end{array}$ & Ref. \\
\hline $\mathrm{Pt}_{38} \mathrm{Ir} \mathrm{NCs} / \mathrm{C}$ & 1.80 & 0.45 & $21 \%$ & in situ FTIR & this work \\
\hline $\mathrm{PtIrSnO}_{2} / \mathrm{C}$ & $1.0^{\mathrm{a}}$ & 0.55 & $17 \%$ & in situ FTIR & 14 \\
\hline $\mathrm{PtIr}_{1 / 2} \mathrm{SnO}_{2} / \mathrm{C}$ & $0.75^{\mathrm{a}}$ & 0.45 & $6 \%$ b & in situ FTIR & 14 \\
\hline $\mathrm{PtIr}_{1 / 4} \mathrm{SnO}_{2} / \mathrm{C}$ & $0.8^{\mathrm{a}}$ & 0.52 & $4 \% \mathrm{~b}$ & in situ FTIR & 14 \\
\hline $\mathrm{Pt}_{3} \mathrm{Ir} / \mathrm{C}$ & - & - & $11.4 \%{ }^{\mathrm{c}}$ & DEMS & 15 \\
\hline $\mathrm{PtIr}_{3} / \mathrm{C}$ & - & - & $12.1 \%^{\mathrm{c}}$ & DEMS & 15 \\
\hline $\mathrm{Pt}_{1} \mathrm{Rh}_{0.8} / \mathrm{C}$ & $0.14^{\mathrm{d}}$ & 0.65 & - & in situ FTIR & 16 \\
\hline $\mathrm{Pt}_{1} \mathrm{Rh}_{0.58}\left(\mathrm{SnO}_{2}\right)_{0.35} / \mathrm{C}$ & $0.11^{\mathrm{d}}$ & 0.55 & $\begin{array}{c}\text { 1-fold enhanced } \\
\mathrm{CO}_{2} \text { current } \\
\text { density }\end{array}$ & in situ FTIR & 16 \\
\hline $\mathrm{Pt}-\mathrm{Rh}-\mathrm{SnO}_{2} / \mathrm{C}$ & $15^{\mathrm{e}}$ & 0.36 & - & in situ FTIR & 17 \\
\hline $\mathrm{Pt}_{39} \mathrm{Pd}_{33} \mathrm{Rh}_{28} / \mathrm{C}$ & $0.38^{f}$ & $0.35^{\mathrm{g}}$ & - & in situ FTIR & 18 \\
\hline $\begin{array}{c}\mathrm{Pt}_{37} \mathrm{Rh}_{20}-\mathrm{O}_{21-} \\
\left(\mathrm{SnO}_{2}\right)_{43} / \mathrm{C}\end{array}$ & $0.3^{\mathrm{d}}$ & - & $17 \% \%^{\mathrm{h}}$ & $\begin{array}{l}\mathrm{CO}_{2} \text { micro- } \\
\text { electrode }\end{array}$ & 19 \\
\hline $\mathrm{Pt}_{28} \mathrm{Rh}_{72} / \mathrm{C}$ & $0.008^{\mathrm{i}}$ & 0.55 & - & in situ FTIR & 20 \\
\hline $\begin{array}{c}\mathrm{Pt}_{9} \mathrm{Rh}_{1} \\
\text { cube/graphene }\end{array}$ & 1.3 & $\begin{array}{c}0.2 \text { vs. } \\
\mathrm{Ag} / \mathrm{AgCl}\end{array}$ & - & in situ FTIR & 21 \\
\hline $\mathrm{Pt}_{65} \mathrm{Rh}_{10} / \mathrm{SnO}_{2} / \mathrm{C}$ & $1.6^{\mathrm{j}}$ & - & $10 \%$ & HPLC & 22 \\
\hline
\end{tabular}

${ }^{a}$ based on mass specific activity; ${ }^{b}$ measured at $0.8 \mathrm{~V}$ vs. RHE; ${ }^{\mathrm{c}}$ measured at $0.7 \mathrm{~V}$ vs. RHE; ${ }^{\mathrm{d}}$ based on mass activity; ${ }^{\mathrm{e}}$ Electrocatalysts contain $30 \mathrm{nmol} \mathrm{Pt,} 8 \mathrm{nmol} \mathrm{Rh}$ and $60 \mathrm{nmol} \mathrm{SiO}{ }_{2} ;{ }^{\mathrm{f}}$ scan rate of $1 \mathrm{mV} / \mathrm{s}$; ${ }^{\mathrm{g}} 0.35 \mathrm{~V}$ vs. NHE; h measured at $0.35 \mathrm{~V}$ vs $\mathrm{Ag} / \mathrm{AgCl} ;{ }^{\mathrm{i}}$ scan rate of $5 \mathrm{mV} / \mathrm{s} ;{ }^{\mathrm{j}} 1 \mathrm{M} \mathrm{C}_{2} \mathrm{H}_{5} \mathrm{OH}+0.1 \mathrm{M} \mathrm{HClO}_{4}$ with scan rate of $20 \mathrm{mV} / \mathrm{s}$ 


\section{References}

1. Chang, Q.; Xu, Y.; Duan, Z.; Xiao, F.; Fu, F.; Hong, Y.; Kim, J.; Choi, S.-I.; Su, D.; Shao, M., Structural Evolution of Sub-10 nm Octahedral Platinum-Nickel Bimetallic Nanocrystals. Nano Lett. 2017, 17, 3926-3931.

2. Craig, J., In Practical Surface Analysis, Auger and X-Ray Photoelectron Spectroscopy; Briggs, D, and Seah, M.P., Eds.; Elsevier: New York, 1991, pp 657-677.

3. Jiang, Z.; Zhang, Q.; Liang, Z.; Chen, J. G., Pt-Modified TaC as an Efficient Electrocatalyst for Ethanol Oxidation in Acid and Alkaline Electrolytes. Appl. Catal., B. 2018, 234, 329-336.

4. Hohenberg, P., P. Hohenberg and W. Kohn, Inhomogeneous Electron Gas. Phys. Rev. 1964, 136, B864.

5. Kresse, G.; Furthmüller, J., Efficient Iterative Schemes for Ab Initio Total-Energy Calculations using a Plane-Wave Basis Set. Phys. Rev. B 1996, 54, 11169.

6. Perdew, J. P.; Wang, Y., Accurate and Simple Analytic Representation of the Electron-Gas Correlation Energy. Phys. Rev. B 1992, 45, 13244.

7. Monkhorst, H. J.; Pack, J. D., Special Points for Brillouin-Zone Integrations. Phys. Rev. B 1976, 13,5188 .

8. Shen, S.; Zhao, T., One-Step Polyol Synthesis of Rh-in-Pd Bimetallic Nanodendrites and their Electrocatalytic Properties for Ethanol Oxidation in Alkaline Media. J. Mater. Chem. A 2013, 1, 906912.

9. Socrates, G., In Infrared and Raman Characteristic Group Frequencies: Tables and Charts. John Wiley \& Sons: New York, 2004, pp 12-26.

10. Kinomoto, Y.; Watanabe, S.; Takahashi, M.; Ito, M., Infrared Spectra of CO Adsorbed on Pt (100), Pt (111), and Pt (110) Electrode Surfaces. Surf. Sci. 1991, 242 , 538-543.

11. Corrigan, D. S.; Krauskopf, E. K.; Rice, L. M.; Wieckowski, A.; Weaver, M. J., Adsorption of Acetic Acid at Platinum and Gold Electrodes: a Combined Infrared Spectroscopic and Radiotracer Study. J. Phys. Chem. A 1988, 92 , 1596-1601.

12. Iwasita, T.; Pastor, E., A DEMS and FTIR Spectroscopic Investigation of Adsorbed Ethanol on Polycrystalline Platinum. Electrochim. Acta 1994, 39 , 531-537.

13. Morris, J. C., Infra-Red and Raman Spectra of Polyatomic Molecules XIX. Acetaldehyde and Acetaldehyded. J. Chem. Phys.1943, 11, 230-235.

14. Li, M.; Cullen, D. A.; Sasaki, K.; Marinkovic, N. S.; More, K.; Adzic, R. R., Ternary

Electrocatalysts for Oxidizing Ethanol to Carbon Dioxide: Making Ir Capable of Splitting C-C Bond. $J$. Am. Chem. Soc. 2012, 135, 132-141.

15. Qu, Y.; Wang, L.; Li, C.; Gao, Y.; Sik, J. K.; Rao, J.; Yin, G., Quantitative Pinhole On-Line Electrochemical Mass Spectrometry Study on Ethanol Electro-Oxidation at Carbon-Supported Pt and IrContaining Catalysts. Int. J. Hydrogen Energy 2017, 42, 228-235.

16. Delpeuch, A. B.; Maillard, F.; Chatenet, M.; Soudant, P.; Cremers, C., Ethanol Oxidation Reaction (EOR) Investigation on $\mathrm{Pt} / \mathrm{C}, \mathrm{Rh} / \mathrm{C}$, and Pt-Based Bi-and Tri-Metallic Electrocatalysts: A DEMS and In Situ FTIR Study. Appl. Catal., B. 2016, 181, 672-680.

17. Kowal, A.; Li, M.; Shao, M.; Sasaki, K.; Vukmirovic, M.; Zhang, J. h.; Marinkovic, N.; Liu, P.; Frenkel, A.; Adzic, R., Ternary $\mathrm{Pt} / \mathrm{Rh} / \mathrm{SnO}_{2}$ Electrocatalysts for Oxidizing Ethanol to $\mathrm{CO}_{2}$. Nat. Mater. 2009, 8, 325.

18. Zhu, W.; Ke, J.; Wang, S.-B.; Ren, J.; Wang, H.-H.; Zhou, Z.-Y.; Si, R.; Zhang, Y.-W.; Yan, C.H., Shaping Single-Crystalline Trimetallic Pt-Pd-Rh Nanocrystals toward High-Efficiency C-C Splitting of Ethanol in Conversion to $\mathrm{CO}_{2}$. ACS Catal. 2015, 5, 1995-2008. 
19. Yang, G.; Frenkel, A. I.; Su, D.; Teng, X., Enhanced Electrokinetics of C-C Bond Splitting during Ethanol Oxidation by using a $\mathrm{Pt} / \mathrm{Rh} / \mathrm{Sn}$ Catalyst with a Partially Oxidized $\mathrm{Pt}$ and $\mathrm{Rh}$ Core and a $\mathrm{SnO}_{2}$ Shell. ChemCatChem 2016, 8, 2876-2880.

20. Silva-Junior, L. C.; Maia, G.; Passos, R. R.; de Souza, E. A.; Camara, G. A.; Giz, M. J., Analysis of the Selectivity of $\mathrm{PtRh} / \mathrm{C}$ and $\mathrm{PtRhSn} / \mathrm{C}$ to the Formation of $\mathrm{CO}_{2}$ during Ethanol Electrooxidation. Electrochim. Acta 2013, 112, 612-619.

21. Rao, L.; Jiang, Y.-X.; Zhang, B.-W.; Cai, Y.-R.; Sun, S.-G., High Activity of Cubic PtRh Alloys Supported on Graphene towards Ethanol Electrooxidation. Phys. Chem. Chem. Phys. 2014, 16, 1366213671.

22. Higuchi, E.; Takase, T.; Chiku, M.; Inoue, H., Preparation of Ternary $\mathrm{Pt} / \mathrm{Rh} / \mathrm{SnO}_{2}$ Anode Catalysts for Use in Direct Ethanol Fuel Cells and their Electrocatalytic Activity for Ethanol Oxidation Reaction. J. Power Sources 2014, 263, 280-287. 